\title{
sciendo
}

\section{Associations Between Physical Effort and DNA Methylation in the Promotor Region of the Dopamine Transporter Gene (DAT1)}

\author{
by \\ Monika Michałowska-Sawczyn"1, Anna Grzywacz², Jolanta Masiak4, \\ Krzysztof Chmielowiec ${ }^{3}$, Jolanta Chmielowiec ${ }^{3}$, Jakub Chycki5, Ewelina Maculewicz, \\ Pawet Cięszczyk $k^{1}$
}

\begin{abstract}
The purpose of this study was to investigate the association between physical effort and DNA methylation in the promoter region of the dopamine transporter gene (DAT1). The research group included 100 athletes (mean age = $22.88, S D=6.35$ ), whereas the control group were 239 healthy male volunteers matched for age (mean age $=21.69, S D$ =3.39). Both, the control and the research group, included individuals with Caucasian origin from the same region of Poland. DNA was extracted from peripheral blood leukocytes using a DNA isolation kit (AEA Biotechnology, Gdynia, Poland). Bisulfite modification of $250 \mathrm{ng}$ DNA was performed using the EZ DNA Methylation Kit (Zymo Research, Orange, CA, USA), according to manufacturer's instructions. The methylation-specific PCR assay was carried out in a Mastercycler epgradient S (Eppendorf, Germany). We observed that the level of general methylation of the CpG island was similar for both groups. Further exploration of individual $C p G$ sites allowed to notice that there were significant differences in methylation status in specific positions. Nonetheless, there was no rule that would indicate either higher or lower methylation of individual sites, four of them were methylated at a higher level (positions 1, 4, 5, 7, 8, 9, 10, 11, $12,13,16,17,18,23,25,26,27,29$ and 30), while one showed an inverse trend (position 3). More precise analysis with the usage of Bonferroni correction for multiple tests indicated that differences in $C p G$ site methylation were mainly increased in several positions and decreased in position 3.
\end{abstract}

Key words: physical activity, DNA methylation; DAT 1 gene; athletes; CpG islands, adaptation.

\section{Introduction}

Physical activity is one of the most important elements in prevention of civilization diseases and diseases connected with the aging process. The advantages of being physically active are much more significant than risks connected with it (Jansson et al., 2015). Physical activity, with adequate volume and intensity, is one of the cheapest and most universal medicine with only small side effects. It can be treated as "home pharmacy" that has been used by many generations (Grzywacz and Jaroń, 2020; Tuka et al., 2017).

Regular physical activity has shown to protect against numerous kinds of cancers in different populations and in various settings. It is well documented that a higher level of physical activity decreases the risk of colorectal, breast,

1 - Faculty of Physical Education, Gdańsk University of Physical Education and Sport, Gdańsk, Poland.

2 - Faculty of Physical Education, University of Rzeszów, Poland.

3 - Faculty of Medicine and Health Science, University of Zielona Góra, Poland.

4 - Neurophysiological Independent Unit, Department of Psychiatry, Medical University of Lublin, Poland.

5 - Institute of Sport Sciences, The Jerzy Kukuczka Academy of Physical Education in Katowice, Poland

6 - Department of Biomedical Sciences, Faculty of Physical Education, Jozef Pilsudski University of Physical Education in Warsaw,

Poland. 
and endometrial cancer (Friedenreich et al., 2010; Kyu et al., 2013). There are new data suggesting the crucial role of exercise in prevention of other types of cancer. A current pooled analysis of 1,44 million individuals allows to notice the extended protective effects connected with head and neck, esophageal, lung, kidney, blood, and bladder cancers without any dependence on the body mass index (Moore et al., 2016). Hence, it can be concluded that the influence of physical inactivity is of high importance in different cancers. Data from 2013 show that nearly $7 \%$ of colorectal and breast cancer cases worldwide occur because of physical inactivity, what created a total healthcare cost of $\$ 5.2$ billion for only those two cancers (Ding et al., 2016). The biological mechanisms influencing cancer risk in connection with physical inactivity has been analyzed for healthy populations in recent randomized controlled trials (Campbell et al., 2012; Friedenreich et al., 2014; Monninkho et al., 2007; Van Gemert et al., 2013). DNA methylation is one of the mechanisms recently identified, but still poorly understood in relation to physical inactivity and carcinogenesis prevention. The process of aging and exposure to carcinogenic agents can dysregulate patterns of DNA methylation, what can provoke genomic instability and improper gene expression (Berdasco and Esteller, 2010; Boyne et al., 2018; Jones et al., 2015; Kochmanski et al., 2017).

Exercise and dietary interventions, which are environmental stimuli, can be elements modifying DNA methylome at a global and genespecific level (Alegría-Torres et al., 2011). The process of hypomethylation after exercise was observed for both skeletal muscles (Nitert et al., 2012; Rowlands et al., 2014; Seaborne et al., 2018) and blood leukocytes (Denham et al., 2015, 2016; Dimauro et al., 2016). Hypomethylation was observed in skeletal muscles after exercise (Bajpeyi et al., 2017; Barrès et al., 2012; Lane et al., 2015; Seaborne et al., 2018), however, the only research considering DNA methylation in leukocytes in the same situation did not allow to detect any changes in DNA methylation (RobsonAnsley et al., 2014). Considering the small number of publications that discuss the impact of acute exercise on DNA methylation in leukocytes, the researchers suggest an epigenetic influence connected with remodeling of the leukocyte transcriptome (Büttner et al., 2007; Connolly et al.,
2004; Gjevestad et al., 2015; Hunter et al., 2019).

Phenotype transmission and the occurrence of different diseases, both seem to be induced by epigenetic mechanisms, among them DNA methylation (Fraga et al., 2005; Gluckman et al., 2009; Ling et al., 2007; Ronn et al., 2008; Sandovici et al., 2011). The epigenetic pattern is mostly imprinted in early life stages, but its modulating potential connected with gene expression and environmental factors influencing phenotypic traits is still observed later in life (Rönn et al., 2013). Changes most often taking place in differentiated mammalian cells include DNA methylation, usually occurring in the context of CG dinucleotides (CpGs) and is connected with repression of genes (Bird, 2002). The stimuli which can provoke changes in epigenetic profiles can be divided into environmental, behavioral, psychological and pathological. What is also important the epigenetic changes are more common than mutations (Feinberg and Irizarry, 2010). Furthermore, genetic variation not connected with a phenotype could affect the number of variability of that phenotype through epigenetic mechanisms, among them DNA methylation. Regular exercise and the mechanism of its longlasting influence are still not well understood, hence many projects concentrate on cellular and molecular changes in skeletal muscles. Current knowledge about DNA methylation in human skeletal muscles emphasizes changes occurring in the epigenetic pattern as an effect of long-term exercise (Rönn et al., 2013). Animal models are applied to analyze numerous physiological and behavioral phenotypes in the context of regulatory influence of DNA methylation. What is important, there are proves showing that it is involved in neuronal and brain development (Watson et al., 2015; Wilson and Sengoku, 2012; Spiers et al., 2015) In human studies, the process of unbalanced methylation has been observed among individuals with substance dependency, anxiety, depression, autism, schizophrenia, and bipolar disorder (Grzywacz et al., 2020; Renthal and Nestler, 2008; Schmitt et al., 2014; Spiers et al., 2015; Tuesta and Zang, 2014)

Since in our project the research group was composed of martial arts athletes, we selected the area of the gene connected with dopamine and dopaminergic transmission to be analyzed. 
Dopamine is the substance often considered an element responsible for making the so called "risky decisions". Worth mentioning is also the "mesolimbic reward system" that mediates in reward psychopharmacology influenced by a physical effort and other factors. Nonetheless, in this case the brain region of the ventral tegmental area, where neurons of the dopaminergic system are situated, and the nucleus accumbens, which is functionally connected to it, are called the "pleasure center" and dopamine itself is called the "pleasure neurotransmitter". Hence, when considering the above mentioned system, we can assume that it can be treated as one of the key determinants of starting and continuing athletic training. Thus, the element influencing taking up and continuing athletic training and possibility of sport success, is the interaction of genetically determined temperament and the environmentally determined character. It is also worth to emphasize additional, physiological reasons to begin studies analyzing the genetic mechanisms determining operations of the dopaminergic system in the context of physical effort and sport. Noticing the fact that dopamine, as a neurotransmitter, is also engaged in neural transmission, e.g. in the extrapyramidal system, one could argue that it could also be of fundamental importance to the level of motor coordination. Some studies on the animal model have noticed that in specific situations of dopamine stimulation deficit mammals become immobile (akinetic), and increased dopamine stimulation provokes greater mobility.

In the context of numerous studies and reports, in our project we tried to consider the methylation process in the group of athletes training regularly in comparison with control subjects that included healthy people, who were not regularly engaged in physical activity. The dopamine transporter DAT1 and methylation in the promoter region were chosen to be analyzed.

\section{Methods}

\section{Participants}

The research group included 100 athletes (mean age $=22.88, \mathrm{SD}=6.35$ ), whereas the control group included 239 healthy male volunteers matched for age (mean age $=21.69, \mathrm{SD}=3.39$ ). Both, the control and the research group, included individuals with Caucasian origin from the same region of Poland. The study was conducted among 100 Polish healthy (no prior history of substance dependency or psychosis) male combat athletes aged $22.88 \pm 6.35$ (MMA, $\mathrm{n}=$ 23; judo, $\mathrm{n}=40$; boxing, $\mathrm{n}=5$; karate, $\mathrm{n}=15$; kickboxing, $\mathrm{n}=15$; wrestling, $\mathrm{n}=2$ ). Various methods were used to obtain the samples, including targeting national teams and providing information to national coaching personnel and athletes attending training camps. All athletes and controls were Caucasian to reduce the possibility of racial gene skewing and to overcome any potential problems due to population stratification.

\section{Methylation status assessment}

DNA was extracted from peripheral blood leukocytes using a DNA isolation kit (A\&A Biotechnology, Gdynia, Poland) as previously described and stored at $-20^{\circ} \mathrm{C}$. Bisulfite modification of $250 \mathrm{ng}$ DNA was performed using the EZ DNA Methylation Kit (Zymo Research, Orange, CA, USA), according to manufacturer's instructions. The methylation-specific PCR assay was carried out in a Mastercycler epgradient $S$ (Eppendorf, Germany).

Primer oligonucleotides were obtained from Genomed.pl (Warsaw, Poland). Primer sequences were designed using methprimer (http://www.urogene.orgbin/methprimer/.cgi).

The status of the DAT1 promoter (ENSG00000142319) was assessed by PCR using primers specific to a fragment of the gene, i.e., DATF: 5'-GGTTTTTGTTTTTTTTATTGTTGAG-3'; DATR: $\quad 5$ 'AAATCCCCTAAACCTAATCCC- 3 ' The PCR conditions in order to amplify the 447-bp fragment covering $33 \mathrm{CpG}$ sites in DAT1 gene promoter were as follows: initial denaturation $\left(94^{\circ} \mathrm{C} / 5 \mathrm{~min}\right)$, followed by 35 cycles $\left(94^{\circ} \mathrm{C} / 61^{\circ} \mathrm{C} / 72^{\circ} \mathrm{C}\right.$, 25 s each step) with final elongation at $72^{\circ} \mathrm{C}$ for $5 \mathrm{~min}$. The concentration of magnesium chloride ions was $2.5 \mathrm{mM}$. After the amplification assay, PCR products were subjected to sequencing as previously described (Kochmanski et al., 2017). Briefly, samples were verified by sequencing using the BigDye v3.1 kit (Applied Biosystems, Darmstadt, Germany) and separation by ethanol extraction using the ABI Prism 3130XL (Applied Biosystems, Darmstadt, Germany) in a $36 \mathrm{~cm}$ capillary in a POP7 polymer, using the reverse primer.

Sequencing chromatograms were 
analyzed using 4peaks software (Mek \& Tosj, Amsterdam, The Netherlands). Methylation of cytosine was considered positive, when the $\mathrm{G} / \mathrm{A}+\mathrm{G}$ ratio reached at least $20 \%$ of a total signal (Figure 1).

\section{Assessment of the ability to bind transcription} factors

To analyze transcription binding sites for the DAT1 promoter region, PROMO software was used (http://alggen.lsi.upc.es/cgibin/promo_v3/promo/promoinit.cgi?dirDB=TF_8. 3). In PROMO, for the identification of potential binding sites in sequences, weight matrices were constructed from known binding sites extracted from version 8.3 of the TRANSFAC database (http://genexplain.com/transfac/\#section0). The ability of transcription factors to bind individual regions was assessed with different similarity rates i.e. $100 \%, 95 \%$ or $85 \%$.

\section{Statistical analysis}

Data were analyzed using the chisquared test, with $p<0.05$ considered statistically significant (GraphPad Prism 5.0). Bonferroni correction for multiple testing was applied to obtain the Bonferroni critical value.

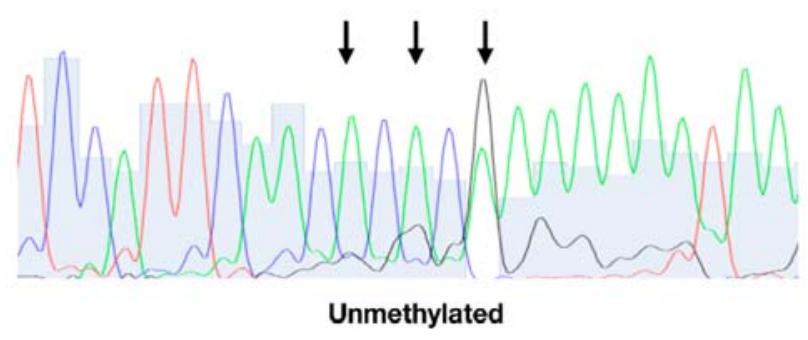

T C CA T T C A A CA C A C A AA A A A AT A A
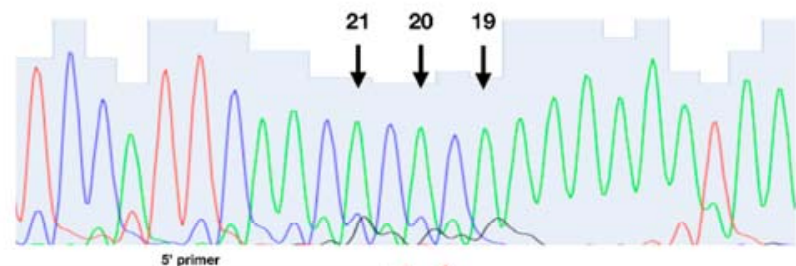

GGTTTTTGTTTTTTTTATTGTTGAGCGCGGGTTGTAGGTTGGAATGGTTG GAGAGTTTTAGGGTTCGTTTGGACGTTTAGGGTAGGGTGTTTACGGGA GTATCGAGGGTATACGGGGAGGAACGTCGGGGTTCGG "GATTTTAGG GGCGACGTATAGAGTTGGGCGCGGTTATTTATTTCGGTGTTTTTTAAGG ATTTGGATATTTTGGGTTTTGGCG GTTTCGGGGGTTTTATTTTTTCGCGC GTTGAATGGAAGAAATTTCGTTCGGGTATTTCGGAAGGAAAGTTTCGG AGTTTATTCGGTTTTGGAGTCGGATATTAATCGTTAGGGTTTTTTAGGTTC GITTCGGGAAATGGTTTTTTTAGGCGAGTGCGAGGCGGGTTTTTCGGTT TCGATGTAGGCGTATTAGATGTCGGTAAGGCGAAATCCCCTAAACCTAA TCCC $3^{3}$ primer

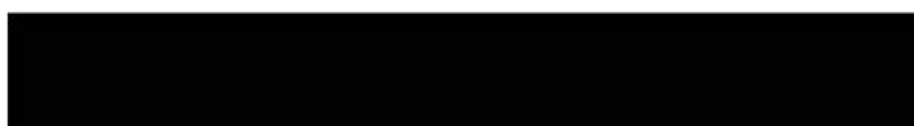

Figure 1

An assessment of a methylation status of individual CpG sites in the DAT1 promoter. (A) The representative result of the positive (top) and negative (bottom) methylation statuses; (B) the sequence of the analyzed DAT1 promoter. Numbers were assigned to individual sites in the studied region starting from 50. The methylation status of individual $C p G$ sites was detected with a cut-o level at $20 \%$ of the G/A G ratio using 4Peaks software (Mek \& Tosj, Amsterdam, The Netherlands) 
Table 1

Methylation status of 33 DAT1 CpG sites in sports and control group. A group of 100 athletes and 239 control individuals were studied to compare the methylation status in indicated $C p G$ sites. The Chi square test and Spearman correlation were used. $\chi^{2}(p)$, Chi square; OR, odds ratio; $C I$, Confidence Interval; $R(p)$, Spearman correlation $(-95 \%,+95 \%) .{ }^{*}$ Bonferroni correction was applied to get the Bonferroni critical value

\begin{tabular}{|c|c|c|c|c|c|c|}
\hline CpG site & Studied group & $\begin{array}{c}\text { methylation } \\
\text { status (\%) }\end{array}$ & $\chi^{2}(\mathrm{p})$ & OR & $\begin{array}{c}95 \% \text { CI } \\
(-95 \%,+95 \%)\end{array}$ & $\begin{array}{c}\mathrm{R} \text { rang Spearman } \\
\mathrm{R}(\mathrm{p})\end{array}$ \\
\hline \multirow[t]{2}{*}{$1^{*}$} & sports N (100) & $74 \%$ & $32.80(.00001)$ & .232 & $(.138, .390)$ & $-.312(.00001)$ \\
\hline & control N (239) & $40 \%$ & & & & \\
\hline \multirow[t]{2}{*}{2} & sports N (100) & $70 \%$ & $.142(.706)$ & 1.103 & $(.661,1.845)$ & $.021(.707)$ \\
\hline & control N (239) & $72 \%$ & & & & \\
\hline \multirow[t]{2}{*}{$3^{*}$} & sports N (100) & $78 \%$ & $20.471(.00001)$ & 4.838 & $(2.326,10.065)$ & $.247(.00001)$ \\
\hline & control N (239) & $94 \%$ & & & & \\
\hline \multirow[t]{2}{*}{$4^{*}$} & sports N (100) & $68 \%$ & $85.746(.00001)$ & .093 & $(.054, .160)$ & $-.505(.00001)$ \\
\hline & control N (239) & $17 \%$ & & & & \\
\hline \multirow[t]{2}{*}{$5^{*}$} & sports N (100) & $56 \%$ & $17.983(.00002)$ & .359 & $(.222, .581)$ & $-.231(.00002)$ \\
\hline & control N (239) & $31 \%$ & & & & \\
\hline \multirow[t]{2}{*}{6} & sports N (100) & $12 \%$ & $5.064(.024)$ & .392 & $(.170, .907)$ &,$- 122(.0244)$ \\
\hline & control N (239) & $5 \%$ & & & & \\
\hline \multirow[t]{2}{*}{$7^{*}$} & sports N (100) & $32 \%$ & $25.410(.00001)$ & .229 & $(.126, .418)$ & $-.275(.00001)$ \\
\hline & control N (239) & $10 \%$ & & & & \\
\hline \multirow[t]{2}{*}{$8^{*}$} & sports N (100) & $16 \%$ & $18.601(.00002)$ & .161 & $(.064, .405)$ & $-.236(.00001)$ \\
\hline & control N (239) & $3 \%$ & & & & \\
\hline \multirow[t]{2}{*}{$9^{*}$} & sports N (100) & $56 \%$ & $14.240(.00016)$ & .403 & $(.250, .650)$ & $-.206(.00014)$ \\
\hline & control N (239) & $34 \%$ & & & & \\
\hline \multirow[t]{2}{*}{$10^{*}$} & sports N (100) & $60 \%$ & $22.254(.00001)$ & .319 & $(.196, .517)$ & $-.257(.00001)$ \\
\hline & control N (239) & $32 \%$ & & & & \\
\hline \multirow[t]{2}{*}{$11^{*}$} & sports N (100) & $20 \%$ & $23.336(.00001)$ & .159 & $(.069, .363)$ & $-.264(.00001)$ \\
\hline & control N (239) & $4 \%$ & & & & \\
\hline \multirow[t]{2}{*}{$12^{*}$} & sports N (100) & $64 \%$ & $48.398(.00001)$ & .179 & $(.108, .297)$ & $-.379(.00001)$ \\
\hline & control N (239) & $24 \%$ & & & & \\
\hline $13^{*}$ & sports N (100) & $28 \%$ & $37.290(.00001)$ & .126 & $(.059, .265)$ & $-.333(.00001)$ \\
\hline & control N (239) & $5 \%$ & & & & \\
\hline 14 & sports N (100) & $85 \%$ & $.121(.728)$ & .891 & $(.466,1.703)$ & $-.019(, 729)$ \\
\hline & control N (239) & $83 \%$ & & & & \\
\hline 15 & sports N (100) & $83 \%$ & $.071(.789)$ & .919 & $(.496,1.705)$ & $-.015(.790)$ \\
\hline & control N (239) & $82 \%$ & & & & \\
\hline $16^{*}$ & sports N (100) & $81 \%$ & $19.601(.00001)$ & .293 & $(.167, .513)$ & $-.241(.00001)$ \\
\hline & control N (239) & $56 \%$ & & & & \\
\hline $17^{*}$ & sports N (100) & $52 \%$ & $21.523(.00001)$ & .321 & $(.197, .524)$ & $-.253(.00001)$ \\
\hline & control N (239) & $26 \%$ & & & & \\
\hline $18^{*}$ & sports N (100) & $19 \%$ & 16.239 (.00006) & .228 & $(.106, .491)$ & $-.220(.00005)$ \\
\hline & control N (239) & $5 \%$ & & & & \\
\hline 19 & sports N (100) & $98 \%$ & $.089(.765)$ & .782 & $(.155,3,944)$ & $-.016(.766)$ \\
\hline & control N (239) & $97 \%$ & & & & \\
\hline 20 & sports N (100) & $40 \%$ & $.293(.588)$ & 876 & $(.542,1,415)$ & $-.029(.589)$ \\
\hline & control N (239) & $37 \%$ & & & & \\
\hline 21 & sports N (100) & $66 \%$ & $.078(.780)$ & .932 & $(.569,1.524)$ & $-.015(.780)$ \\
\hline & control N (239) & $64 \%$ & & & & \\
\hline 22 & sports N (100) & $95 \%$ & $.001(.974)$ & .982 & $(.337,2.865)$ & $-.002(.974)$ \\
\hline & control N (239) & $95 \%$ & & & & \\
\hline $23^{*}$ & sports N (100) & $44 \%$ & 41.535 (.00001) & .178 & $(.102, .310)$ & $-.351(.00001)$ \\
\hline & control N (239) & $12 \%$ & & & & \\
\hline 24 & sports N (100) & $70 \%$ & $.387(.533)$ & .852 & $(.513,1.412)$ & $-.033(.535)$ \\
\hline & control N (239) & $67 \%$ & & & & \\
\hline $25^{*}$ & sports N (100) & $58 \%$ & $23.141(.00001)$ & .311 & $(.192, .506)$ & $-.262(.00001)$ \\
\hline & control N (239) & $30 \%$ & & & & \\
\hline $26^{*}$ & sports N (100) & $66 \%$ & $19.285(.00001)$ & .341 & $(.209, .556)$ & $-.240(.00001)$ \\
\hline & control N (239) & $40 \%$ & & & & \\
\hline $27^{*}$ & sports N (100) & $52 \%$ & $66.183(.00001)$ & .114 & $(.065, .201)$ &,$- 444(.00001)$ \\
\hline & control N (239) & $11 \%$ & & & & \\
\hline 28 & sports N (100) & $66 \%$ & $.625(.429)$ & .821 & $(.503,1.339)$ & $-.043(.431)$ \\
\hline & control N (239) & $61 \%$ & & & & \\
\hline $29^{*}$ & sports N (100) & $36 \%$ & $16,193(.00006)$ & .341 & $(.199, .583)$ & $-219(.00005)$ \\
\hline & control N (239) & $16 \%$ & & & & \\
\hline $30^{*}$ & sports N (100) & $32 \%$ & $36.485(.00001)$ & .154 & $(.079, .298)$ &,$- 329(.00001)$ \\
\hline & control N (239) & $7 \%$ & & & & \\
\hline 31 & sports N (100) & $6 \%$ & $.069(.791)$ & 1.139 & $(.432,3.002)$ & ,014 (.792) \\
\hline & control N (239) & $7 \%$ & & & & \\
\hline 32 & sports N (100) & $56 \%$ & $6.858(.0088)$ & 1.901 & $(1.171,3.086)$ & $.142(.0087)$ \\
\hline & control N (239) & $71 \%$ & & & & \\
\hline 33 & sports N (100) & $66 \%$ & $9.291(.0023)$ & 2.247 & $(1.326,3.810)$ & $.166(.0022)$ \\
\hline & control N (239) & $81 \%$ & & & & \\
\hline
\end{tabular}




\section{Results}

We analyzed the influence of regular training on DAT1 promoter methylation status in peripheral blood leucocytes of subjects in a sideby-side comparison with healthy individuals. We observed that the level of general methylation of the CpG island was similar for both groups. Further exploration of individual $\mathrm{CpG}$ sites allowed to notice that there were significant differences in methylation status in positions shown in Table 1. Nonetheless, there was no rule that would indicate either higher or lower methylation of individual sites, four of them were methylated at a higher level (positions 1, 4, 5, 7, 8, $9,10,11,12,13,16,17,18,23,25,26,27,29$ and 30), while one showed an inverse trend (position 3 ). More precise analysis with the use of the Bonferroni correction for multiple tests indicated that the $\mathrm{CpG}$ site methylation was higher mainly in positions $1,4,5,7,8,9,10,11,12,13,16,17,18$, $23,25,26,27,29$ and 30 and lower in position 3.

\section{Discussion}

In the current study, we analyzed $33 \mathrm{CpG}$ sites of the promotor region of the DAT1 gene among a sample group of athletes and a control group. The obtained data showed significant differences between the two groups as methylation changes across all sites differed. When comparing the control and the group of athletes, the latter were hypermethylated and some were hypomethylated. What is more, the ability of transcription factors to bind to chosen sites revealed a great number of those regulators of gene expression.

One of the analyzed sites was found to be possible PAX5 transcription factor binding sites (position 3), in which the hypomethylation occurs. This is of great importance, as PAX5 is a transcription factor connected with many processes influencing the development of the nervous system. However, because of the shortage of analysis of DAT1 gene expression in our study group, we could not anticipate the precise role of this finding in connection with dopaminergic transmission. We also observed that both groups represented a similar general methylation level of the $\mathrm{CpG}$ islands. Interesting is the fact that more precise exploration of individual CpG sites status allowed to conclude about significant methylation status differences in positions shown in Table 1. Hypermethylation is evident in site 1 (74 vs. $40 \%$ ), site 4 and 5, 7-13, 16$18,23,25-27,29,30$ in the research group.

It is difficult to address the results of methylation analysis in the promoter of the DAT1 gene among athletes, because of the fact that such analysis has not been conducted in any competitive groups of athletes. Similar research was conducted by Grzywacz at al. (2000) and indicated changes in island sites in the promoter of the dopamine transporter gene among cannabinoid dependent individuals. However, hypermethylation was observed only in three islands (positions 1, 6 and 28), and there was no association between endophynotype, disease entity, and hypo- or hypermethylation in the promoter of the DAT1 gene. When observing the results obtained for the group of athletes we showed a tendency in the direction of hypermethylation in the research group. However, although we should be cautious with making any conclusion, we did observe decisive hypermethylation, which can be a promising condition for further research in that area and confirmation of the chosen direction connected with the area of the dopamine transporter gene.

However, we need further studies of animal models with the usage of DAT1 knock-out animals or chromatin immunoprecipitation (ChiP) experiments which should be conducted to show which TF or other protein may bind DNA in the DAT1 promoter region. However, it could be difficult to achieve the expected results, as neural development and functionality are changing during the whole lifetime of an individual. Among probable TFs which may possibly bind the DAT1 promoted in chosen sites, SP1 can be found. SP1 is a transcription factor of low specificity that can bind a wide spectrum of target sequences. 


\section{Acknowledgements}

The study was supported by National Science Centre of Poland (No. UMO-2016/21/B/NZ7/01068).

\section{References}

Alegría-Torres JA, Baccarelli A, Bollati V. Epigenetics and lifestyle. Epigenomics [Internet], 2011, 3:267-277

Bajpeyi S, Covington JD, Taylor EM. (2017) Skeletal muscle PGC1 $\alpha-1$ nucleosome position and -260 nt DNA methylation determine exercise response and prevent ectopic lipid accumulation in men. Endocrinology, 2017, 158:2190-2199

Barrès R, Yan J, Egan B. Acute exercise remodels promoter methylation in human skeletal muscle. Cell Metab, 2012, 15:405-411

Berdasco M, Esteller M. Aberrant epigenetic landscape in cancer: how cellular identity goes awry. Dev Cell, 2010, 19(5): 698-711

Bird A. DNA methylation patterns and epigenetic memory. Genes Dev, 2002, 16: 6-21.

Boyne DJ, King WD, Brenner DR, McIntyre JB, Courneya KS, Friedenreich CM. Aerobic exercise and DNA methylation in postmenopausal women: An ancillary analysis of the Alberta Physical Activity and Breast Cancer Prevention (ALPHA) Trial. PLoS One, 2018, 28;13(6):e0198641

Büttner P, Mosig S, Lechtermann A. Exercise affects the gene expression profiles of human white blood cells. J Appl Physiol, 2007, 102:26-36

Campbell KL, Foster-Schubert KE, Alfano CM, Wang CC, Wang CY, Duggan CR. Reduced-calorie dietary weight loss, exercise, and sex hormones in postmenopausal women: randomized controlled trial. J Clin Oncol, 2012, 30(19): 2314-26

Connolly PH, Caiozzo VJ, Zaldivar F. Effects of exercise on gene expression in human peripheral blood mononuclear cells. J Appl Physiol., 2004, 97:1461-1469

Denham J, Marques FZ, Bruns EL. Epigenetic changes in leukocytes after 8 weeks o resistance exercise training. Eur J Appl Physiol., 2016, 116:1245-1253

Dimauro I, Scalabrin M, Fantini C. Resistance training and redox homeostasis: correlation with ageassociated genomic changes. Redox Biol., 2016, 10:34-44

Feinberg AP, Irizarry RA. Evolution in health and medicine Sackler colloquium: Stochastic epigenetic variation as a driving force of development, evolutionary adaptation, and disease. Proc Natl Acad Sci U $S$ A, 2010, 107 Suppl 1:1757-1764

Fraga MF, Ballestar E, Paz MF, Ropero S, Setien F. Epigenetic difference arise during the lifetime of monozygotic twins. Proc Natl Acad Sci U S A, 2005, 102: 10604-10609

Friedenreich CM, Neilson HK, Lynch BM. State of the epidemiological evidence on physical activity and cancer prevention. Eur J Cancer., 2010, 46(14): 2593-604

Friedenreich CM, MacLaughlin S, Neilson HK, Stanczyk FZ, Yasui Y, Duha A. Study design and methods for the Breast Cancer and Exercise Trial in Alberta (BETA). BMC cancer, 2014, 14: 919

Gjevestad GO, Holven KB, Ulven SM. Effects of exercise on gene expression on inflammatory markers in human peripheral blood cells: a systematic review. Curr Cardiovasc Risk Rep., 2015, 9:34

Gluckman PD, Hanson MA, Buklijas T, Low FM, Beedle AS. Epigenetic mechanisms that underpin metabolic and cardiovascular diseases. Nat RevEndocrinol, 2009, 5: 401-408

Grzywacz A, Barczak W, Chmielowiec J, Chmielowiec K, Suchanecka A, Trybek G, Masiak J, Jagielski P, Grocholewicz K, Rubiś B. Contribution of Dopamine Transporter Gene Methylation Status to Cannabis Dependency. Brain Sci., 2020, 23;10(6):400

Grzywacz E., Jaroń A. Well-being and mental health - diet, supplements, exercise or sleep? A review of reports from the last five years. Baltic Journal of Health and Physical Activity, 2020, 12(2), 73-82 
Hornowska, E. Temperamentalne uwarunkowania zachowania. Poznań: Bogucki Wydawnictwo Naukowe, 2003

Hunter DJ, James L, Hussey B, Wadley AJ, Lindley MR, Mastana SS. Impact of aerobic exercise and fatty acid supplementation on global and gene-specific DNA methylation. Epigenetics, 2019, 14(3):294-309

Jansson E, Hagströmer M, Anderssen SA. Physical activity--new paths and choices in the recommendations for adults. Lakartidningen., 2015, 17:112

Jones MJ, Goodman SJ, Kobor MS. DNA methylation and healthy human aging. Aging cell, 2015, 14(6): 92432

Kochmanski J, Montrose L, Goodrich JM, Dolinoy DC. Environmental Deflection: The Impact of Toxicant Exposures on the Aging Epigenome. Toxicol Sci., 2017, 156(2): 325-35

Kyu HH, Bachman VF, Alexander LT, Mumford JE, Afshin A, Estep K. Physical activity and risk of breast cancer, colon cancer, diabetes, ischemic heart disease, and ischemic stroke events: systematic review and dose-response meta-analysis for the Global Burden of Disease Study. BMJ. 2016; 354: i3857

Lane SC, Camera DM, Lassiter DG. Effects of sleeping with reduced carbohydrate availability on acute training responses. J Appl Physiol., 2015, 119:643-655.

Ling C, Poulsen P, Simonsson S, Ronn T, Holmkvist J. Genetic and epigenetic factors are associated with expression of respiratory chain component NDUFB6 in human skeletal muscle. J Clin Invest, 2007, 117: 3427-3435

Monninkhof EM, Peeters PH, Schuit AJ. Design of the sex hormones and physical exercise(SHAPE) study. BMC public health, 2007, 7: 232

Moore SC, Lee IM, Weiderpass E, Campbell PT, Sampson JN, Kitahara. Association of Leisure-Time Physical Activity With Risk of 26 Types of Cancer in 1.44 Million Adults. JAMA Intern Med., 2016, 176(6): 81625

Nitert MD, Dayeh T, Volkov P. Impact of an exercise intervention on DNA methylation in skeletal muscle from first-degree relatives of patients with type 2 diabetes. Diabetes., 2012, 61:3322-3332

Nowak JZ, Zawilska JB. Receptory I mechanizmy przekazywania sygnału. Wydawnictwo Naukowe PWN, Warszawa, 2004

Renthal, W.; Nestler, E.J. Epigenetic mechanisms in drug addiction. Trends Mol. Med., 2008, 14, 341-350

Ronn T, Poulsen P, Hansson O, Holmkvist J, Almgren P. Age influences DNA methylation and gene expression of COX7A1 in human skeletal muscle. Diabetologia, 2008, 51: 1159-1168

Rönn T, Volkov P, Davegårdh C, Dayeh T, Hall E, Olsson AH, Nilsson E, Tornberg A, Dekker Nitert M, Eriksson KF, Jones HA, Groop L, Ling C. A six months exercise intervention influences the genomewide DNA methylation pattern in human adipose tissue. PLoS Genet., 2013, 9(6):e1003572

Robson-Ansley PJ, Saini A, Toms C. Dynamic changes in dna methylation status in peripheral blood Mononuclear cells following an acute bout of exercise: potential impact of exercise-induced elevations in interleukin-6 concentration. J Biol Regul Homeost Agents., 2014, 28:407-417

Rowlands DS, Page RA, Sukala WR. Multi-omic integrated networks connect DNA methylation and miRNA with skeletal muscle plasticity to chronic exercise in Type 2 diabetic obesity. Physiol Genomics., 2014, 46:747-765

Sandovici I, Smith NH, Nitert MD, Ackers-Johnson M, Uribe-Lewis S. Maternal diet and aging alter the epigenetic control of a promoter-enhancer interaction at the Hnf4a gene in rat pancreatic islets. Proc Natl Acad Sci U S A, 2011, 108: 5449-5454

Schmitt, A.; Malchow, B.; Hasan, A.; Falkai, P. The impact of environmental factors in severe psychiatric disorders. Front. Neurosci., 2014, 8, 19

Seaborne RA, Strauss J, Cocks M. Human skeletal muscle possesses an epigenetic memory of hypertrophy. Sci Rep., 2018, 8:1-17 
Spiers, H.; Hannon, E.; Schalkwyk, L.C.; Smith, R.; Wong, C.C.Y.; O’Donovan, M.C.; Bray, N.J.; Mill, J. Methylomic trajectories across human fetal brain development. Genome Res., 2015, 25, 338-352

Tuesta, L.M.; Zhang, Y. Mechanisms of epigenetic memory and addiction. EMBO J., 2014, 33, 1091-1103

Tuka V, Daňková M, Riegel K, Matoulek M. Physical activity - the Holy Grail of modern medicine?. Vnitr Lek. Fall, 2017, 63(10):729-736

Van Gemert WA, Iestra JI, Schuit AJ, May AM, Takken T, Veldhuis WB. Design of the SHAPE-2 study: the effect of physical activity, in addition to weight loss, on biomarkers of postmenopausal breastcancer risk. BMC cancer., 2013, 13: 395

Watson, C.T.; Szutorisz, H.; Garg, P.; Martin, Q.; Landry, J.A.; Sharp, A.J.; Hurd, Y.L. Genome-wide DNA methylation profiling reveals epigenetic changes in the rat nucleus accumbens associated with crossgenerational effects of adolescent THC exposure. Neuropsychopharmacology., 2015, 40, 2993-3005

Wilson, M.E.; Sengoku, T. Developmental regulation of neuronal genes by DNA methylation: Environmental influences. Int. J. Dev. Neurosci., 2013, 31, 448-451

\section{Corresponding author:}

\section{Paweł Cięszczyk}

Gdańsk University of Physical Education and Sport

ul. Kazimierza Górskiego 1

80-336 Gdańsk, Poland

E-mail: cieszczyk@poczta.onet.pl 